\title{
Introduction to Narrative Phenomenon Model: A Framework for Mapping War Stories that Travel through Generations
}

Chandi Raj Dahal

\begin{abstract}
This article relies upon cultural trauma theory for the basic understanding of storytelling in a post-traumatic situation and presents its findings based on researcher's own observation of a post conflict situation of decade long armed conflict in Nepal. It introduces a communication model to explain the storytelling phenomenon that emerges during and after any violent situation and that exists through newer generations. First, the article discusses some theories related to trauma stories and sociology of generational differences. Second, it proposes Narrative Phenomenon Model as a new tool that can map the journey of trauma stories created by those exposed to war or violent events. Third, it discusses how narratives get created, modified or transformed into multiple truths.
\end{abstract}

Keywords: Communication, Narrative Phenomenon, Post Conflict, Storytelling, War stories

\section{Introduction}

Storytelling exists in many forms and formats. Some stories are told verbally in person, which remain undocumented but pass through generations in the form of artwork, folklores, 
songs, other forms of performing arts and through passing on family stories to children. Likewise, storytelling has many formats such as drama, testimony, interview, actuality, news report, discussion, game, demonstration among others. Any of these forms and formats of storytelling involves certain kind of filters, noise and intended or unintended gatekeeping. When it comes to the domain of mediated communication, stories are also somehow dependent upon the type of channel or medium because the channel comes with chances for noise and often with in-built features that distort or emphasize the content being delivered.

Storytelling is a common phenomenon that people involve in almost every day; they consume media news which tell stories of the day or any new information related to them and their society at large. However, some stories are more important than others; for example, trauma stories generating from the war, conflicts or other major violence not just impact people of the generation who faced such atrocities but also builds upon their perceptions that their past was full of traumatic experiences. No matter how immediately, storytelling during war impacts peace process based on how and what stories are told to the public whereas in the post conflict situation, it impacts the peace building as a whole. Storytelling can be a healing process for some people while it can also be a sensitive issue which if ruined can lead to the worst situation instead. Thus, 'who tells a story with what motive' is something that matters.

In this regard, it is equally pertinent to study how stories get created, modified and transformed. Scholars have tried to explain some of these issues through theories of cultural and 
collective trauma. However, this article attempts to provide a holistic picture to understand the phenomenon of post-conflict storytelling.

\section{Cultural Trauma Theory}

Scholars like Jeffrey Alexander, Ron Eyerman, Bernad Giesen, Neil Smelser and others have produced substantive literatures on cultural trauma and collective trauma. Cultural traumas, as "processes of meaning making and attribution" explain how trauma dramas get created (Eyerman, 2012). Such traumas are based on the narratives about some powerful and shocking experiences or occurrences, which may possibly be shaped by the narrators' emotional reactions. According to Eyerman, there are two sides to a cultural trauma-an emotional experience and an interpretative reaction. Within such narrations, the determining variables are victims, good/evil, perpetrators. Similarly, collective traumas are the sufferings from symbolic rendering that emerges from the collective reconstruction and imagination of historical events. These traumas are formed as schemas, among a group of people, with social meanings to any events that a generation of certain community, society or a country had historically faced. Thus, collective traumas are reflections of neither individual sufferings nor of actual events, which are heavily driven by fictional statements or narratives within a context of cultural sociology (Alexander, 2012). Often used as tools for analyzing social construction of significant traumatic events, this theory helps in mapping previously occurred sufferings or events; extreme political repression, war or outrages. 
Although within the same contemporaries of all ages are exposed to the same events, the older age groups will already have formed their own natural view of these events. As a result, what is a shared experience becomes stratified by multiplicity of perspectives that are, so to speak, generational. Each age group brings its own point of view to bear on these events (Roberts \& Lang, 2001). As cultural traumas are built through the narratives of the past events, they can only be retrospective. "It is only after the passing of time- how much exactly is uncertain - that we can know if the effect of a traumatic occurrence is still felt, still alive" (Eyerman, 2011, P.32). Here are some concepts from the works of Eyerman on cultural trauma:

\begin{tabular}{|l|l|}
\hline Concept & Meaning \\
\hline Traumatic events & $\begin{array}{l}\text { Powerful or shocking incidents or } \\
\text { violence }\end{array}$ \\
\hline Trauma drama & $\begin{array}{l}\text { Discursive process that makes } \\
\text { visible, articulates, and gives } \\
\text { meaning and words to what is } \\
\text { strongly felt but not grasped }\end{array}$ \\
\hline Chosen trauma & $\begin{array}{l}\text { the shared mental trauma that the } \\
\text { group's ancestors suffered }\end{array}$ \\
\hline Carrier groups & $\begin{array}{l}\text { collective agents of trauma process } \\
\text { who communicate the collective pain } \\
\text { of their group. }\end{array}$ \\
\hline
\end{tabular}

\section{Sociology of generations}

The term generation has many connotations. All the meanings implied in the works of writers, journalists, authors and other 
communicators all over the world are difficult to trace out as most of the times they are context specific. Sometimes the term 'generation' is used to denote certain age-groups while in some other instances, it refers to certain cohort groups born within some historical timeframes. The most influential works on the study of generations was initially led by Karl Mannheim, who was mostly inspired by social movements initiated by young people since the 18th century. He argues that generation forms an identity during the formative years of an individual's life, i.e. youth (Mannheim, 1952). According to Mannheim, there are three important characteristics to forming a generation: a) generation as a location; b) generation as an actuality and c) generational units. Mannheim (as cited in Alwin \& McCammon, 2003, p.24) argues that "having shared the same formative experiences contributes to a unique worldview or frame of reference that can be a powerful force in people's lives"; meaning that a group of people sharing same socio-cultural phenomenon will have similar understanding about their lived experiences in relation to the time and space as they grow up. This can be further understood as the idea that members who encounter certain social changes within a given timeframe will likely construct similar understanding of the social circumstances but different than of those who do not. However, understanding and interpretations of such circumstances depend on individual's prior knowledge and experiences. Likewise, Mannheim (1952) points out that generations emerge only under special historical circumstances and are thus something 'more' than simply age cohorts; they are a group of people of similar age bonded by a shared experience. 


\section{Methodology}

The framework introduced in this article is based on the findings of a narrative research conducted during a ten-day long visit to Rolpa district of Nepal for collecting data from among the people who witnessed or experienced the decade long Maoist conflict. The respondents were identified based on their willingness to share their perceptions about the traumatic experiences they witnessed or the stories they heard about from their earlier generations. Ten respondents from older generation and five from newer generation participated in the unstructured interviews where they shared their stories. The interviews were audio-recorded and later verbatim transcription was done. The analysis techniques borrow the concepts of cultural trauma and generational differences as discussed in the theoretical framework section. Based on those ideas, priori themes were generated to analyze the qualitative data.

\section{Respondents from older generation}

Out of the total respondents, three women had lost their husbands; two of them being involved in the war themselves and third as a victim of the war. Fourth respondent woman comes from a victim's family because her father was killed during the war and she had to migrate to the headquarter.

Deukala Kumari Gharti used to be a rebellion woman who got actively involved in the war during the internal armed conflict in Nepal. She shared her experiences as "the deadliest scenes" that had happened in front of her eyes. In 2003, there was a 
fight in Dang. It was second year of her marriage. When a group of combatants was returning from Lamahi via a guerrilla route, they confronted the army in the village. There were small bazaars in that place. The battle started. While retreating, Deukala's husband died. At that time, she was in the village with her daughter who was just nine months old. Deukala was in the party (Maoists) constantly since 1999 and there were many women like her.

Another woman Geeta Thapa Acharya is from Rolpa municipality. She was born in a poor family 36 years ago. When she was around 10 years old her father died and her mother left her and her siblings. They were five siblings. Her grandfather was already dead but she had grandmother. She was 16 years old when she was linked to a women's association in 1996. She joined the rebellions as a volunteer where she was asked to sing and dance in the cultural groups to motivate the combatants in the fight. She was made an area cadre of the Maoist party. Later during the war, she lost her husband just five months after their marriage.

Unlike the previous two cases, Meena Nepali is a victim of the war because her husband was killed by the Maoists though her family was not involved in the war from any side. Her husband used to be a school teacher in a village. Meena Nepali was 23 years old when her husband was killed. She did not consider for a second marriage. She was neither into Maoist party nor supporting the Nepal Army.

Another respondent Shree Kumari Roka is from a victim's family. She was 18 years old and unmarried when her father was killed by Maoists during the insurgency. Later she got married and now she has two children. She was in Thawang 
during the time of war but later she migrated to the district headquarter in 2003.The researcher also talked to Deuki Gurung and Dhan Kumari Budha, other two female witnesses of the war. Deuki Gurung is around 80 years old. She experienced the conflict as a witness. Some of her relatives died in the war. She was often forced to let the Maoist combatants eat in her house during the war. Dhan Kumari Budha is 22 years old now. She is a full-time teacher at Balkalyan School in Liwang. She was 12 years old when the conflict finally ended. However, she recollects her memories of war. Likewise, a senior teacher from Balkalyan School in Liwang and lawyer, writer and a member of Nepali Congress Mahasamiti were interviewed as two male witnesses of the war. The teacher has been teaching for a long period of time in Balkalyan School. He was a teacher when Krishna Bahadur Mahara (one among the key leaders from the Maoists during and after the conflict) and his colleagues started the war from Rolpa. He has faith upon the Maoist party which used to be the rebellion group. Another witness Madhav Prasad Acharya lives in Rolpa. He is a lawyer by profession. But associates himself to Nepali Congress. Currently, he is a member of the party's Mahasamiti. Besides, he is a writer who has written several stories of the wartime. One of his books, Rolpa ma Dhurudhuru Royera, contains a letter from Meena Nepali's husband, who was killed in the war.

Among other two respondents from the older generations are those directly concerned with the war; one was a commander of Maoists' "People's Liberation Army" and fought the war during the time of the armed conflict whereas another is a victim of the wartime. Mitra Lal Thapa used to be in the Maoists' "People's Liberation Army" during the wartime. He 
was involved in it since 1998. Thapa is 46 years old now. He was one of the commanders of the "People's Liberation Army". He used to lead 750 combatants. Now he is in the village, working as a farmer. Kalam Rokaya, often known as Kalam Baje, from Thawang is a victim of the war. He has been living in Liwang most of the time. He was displaced from Thawang due to insecurity. In 1996, various print media published news accusing him of killing people. People of Thawang called him as a member of Nepali Congress at the time when he did not have much knowledge about politics. His house was captured and destroyed by the Maoists.

\section{Respondents from new generation}

Salina Gharti (name changed) is 18 years old and she has completed tenth grade this year. She studied in a Martyr's Memorial School in Dang as being a daughter of a martyr. While her parents were into Maoist party, involved in the war, she stayed in Jungkot with her grandparents and studied there up to grade three. Later in 2012, she joined the school in Dang. Sangita Budha (name changed) is 15 years old. She was with her mother until she was two years old. Then she came to Liwang because her parents were into Maoist party. Another respondent Siwani Acharya, name changed, is 17 years old. She studies in grade 10 in a school in Liwang. She has a broken family. She grew up in the district headquarter. Likewise, Roshan Budha is 18 years old. He temporarily lives in Liwang as he is studying in a college in Liwang. He comes from a remote village in Rolpa. Likewise, some children were found playing football in a ground in Liwang. After the game completed, they were asked in a group about what war meant 
to them and if they knew anything about Maoist insurgency that had happened in Rolpa in the past. After a while in the conversation, the children opened up a little and expressed their impressions about the war which they had not seen but heard about. These children were between 12-15 years old. Similarly, another group of children were found grinding pebbles in Gurung village. These children were of age between 10-13. They were asked if they had heard about the People's War or conflict or Maoists' war. This group of children also slowly talked about what they knew had happened in their village. Some other respondents like the Chairperson of the Gurung Village Homestay, the house owner lady of the homestay and her father were interviewed as well. However, their answers have been used to substantiate the researcher's knowledge and observation but their narratives have not been included in this article.

\section{Findings and discussions}

Stories of war originate as traumatic events in the lives of the people who encounter any sort of violent occurrences that bring emotional experiences to them. This group of people who consciously live through the period of conflict or war represent the first generation in the narrative process. The emotional experiences then travel in the form of narratives where following elements are visible: 


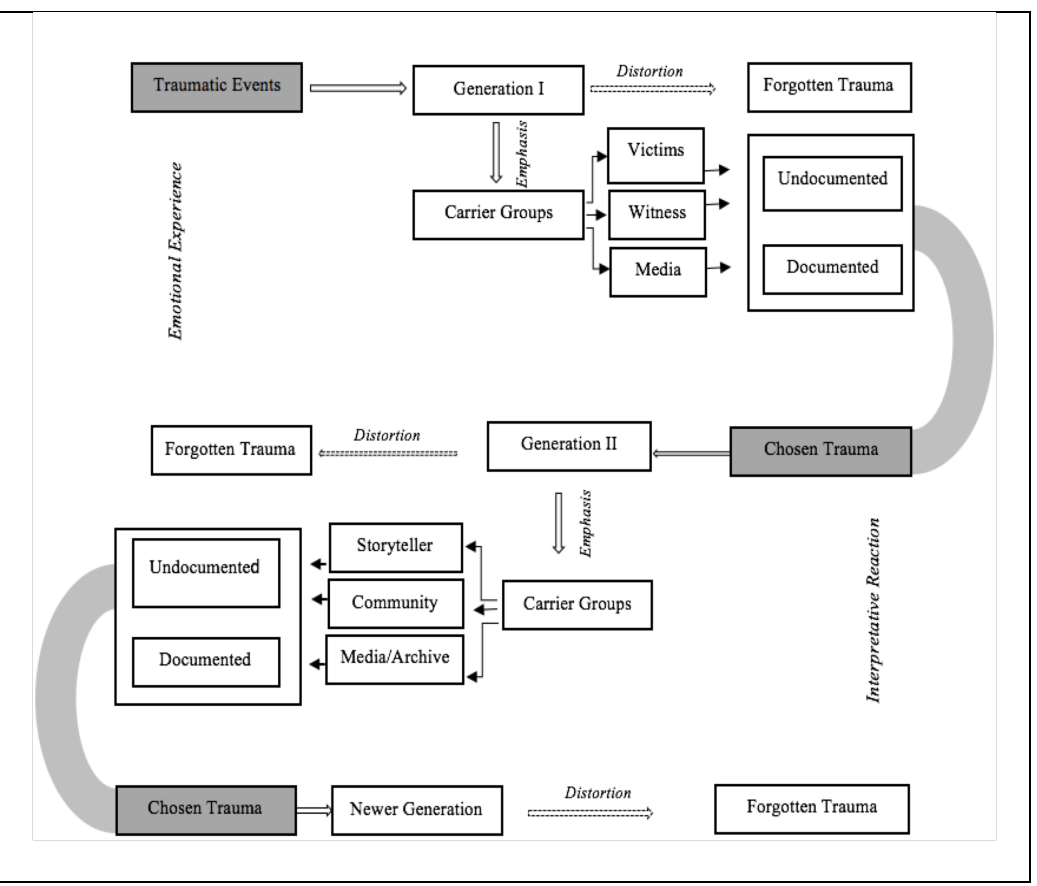

Fig1: Narrative Phenomenon Model

The people who live during the time of war represent the first generation to collect the firsthand experiences of the occurrences of war, conflict or a violent activity. This generation includes only those people who can comprehend the story or at least build some mental pictures of the occurrences. Thus, infants or children who cannot comprehend the trauma do not represent the first generation in the narrative process.

Traumatic events are violent activities that occur during war or conflicts. These events create traumatic impacts in the lives of the people who live through the wartime. They are fights, 
killings, suppressions, moments of pride, short-lived happiness, victory, or any sort of encounters related to the conflict. Most of the respondents interviewed for the purpose of this study accepted that the war naturally demands violence as the only means to solve the problems of the parties involved. Their responses clearly indicated that war brought them the unexpected and strange experiences; particularly to those who became the part of the context. Some who were directly involved in the war and others who become neutral third party as the observers had shared different levels of violent activities. Thus, all of those people who lived through violence have their different experiences and accounts regarding the traumatic occurrences or events. Deukala Kumari Gharti from Rolpa who fought from the rebel group during the war recalls some of her experiences:

It was a disastrous fight in Beni. Many of our friends died. We took many injured friends to the hospital. We had to play a whole new trick for the army if they followed or knew our tracks. In Dhorpatan, they (the Army) attacked us from choppers. It was like a downpour of bullets. Then, we diverted towards Rukum and survived (personal communication, May $18,2018)$.

Another respondent Gita Thapa lost many friends in Myagdi. They were attacked from helicopters while their other injured friends were being taken to the nearby hospital. The Army shot and killed the injured as well. She shares some incidents that happened in front of her eyes:

I was also directly involved in the war in Khara, Myagdi, and in Sishne. I had never seen dead people 
before, but I saw people getting killed in Khara. My friend was shot right in front of me (personal communication, May 18, 2018).

Shree Kumari Roka is from a victim's family. Her father was killed by the rebellions. A Maoist member killed him while he was on his way to Liwang from Sulichaur. Roka describes the traumatic experiences that her family encountered:

It was known that my father was attacked by sharp object in his eyes. He was beaten to death at first. There were bruises on his body. His head was separated from the body and taken 40 meters apart. I was totally broken by this inhumane death (personal communication, May 19, 2018).

A senior teacher from Bal Kalyan School in Rolpa shares the events he witnessed during the time of war. Many people, including him, who saw the battle were very scared. The teacher shares:

Once a Maoist hit a policeman here. He shot him with 20 bullets. It was about 10:45 am. Soon more firings started everywhere. Some Maoists even came dressed as students. They collected their weapons and when the policeman chased them, they ran away and disappeared into the jungle (personal communication, May 19, 2018). 
Stories of Deukala, Gita Thapa, Shree Kumari and the teacher from Bal Kalyan, as shared to this researcher, have travelled all the way to become documented stories now. But their realtime experience that these stories represent were the traumatic events they have experienced.

Among all the traumatic events encountered by an individual during the war, only part of the experiences is given emphasis; not all the events are remembered or considered important enough to be told to others. Thus, in this phenomenon of storytelling, the first generation tells the story to other people of the same or upcoming generations only if they think the stories are worth telling. For example, Deukala said that she likes telling the stories to the newer generation. Although her daughter does not already know most of the things that happened in the past, she has been studying in Martyr's Memorial School in Dang so she somehow knows a little about her parents' involvement in the war. Deukala said that her daughter sometimes asks how her father died:

Sometimes she asks me and I tell her about everything. She has left home for the last two years and now she has curiosity to know new things. She asks about how I got into the party. She asks how her father died. And at such times, I answer to her all the questions (personal communication, May 18, 2018).

Likewise, Mitra Lal Gurung believes that his daughters will like to hear the stories from him. He says that his daughters were born during the war and that the eldest one knows some of the war stories (personal communication, May 18, 2018). 
Another respondent Kalam Rokaya has plans to tell the stories of war to his children. However, some of his children have seen the war already so they have some idea about it while some others are still unaware. Rokaya shares:

The new generation doesn't have any experiences related to civil war. I will tell them someday about the war and the problems we came across. Sometimes they ask about the war. I do share with them my experiences (personal communication, May 18, 2018).

If any stories or traumatic experiences, for any reasons, do not get adequate emphasis or attention, they get distorted. Such distortion may include any kind of noises that do not let the stories to transfer; either forgetting or untold, told ineffectively or with any kind of technical or purposeful hindrances. Such distortion leads to forgotten trauma. Unlike Deukala, Mitra Lal and Kalam Rokaya, Shree Kumari Roka considers that victims of war hesitate to talk about their past incidents. She argues that ex-soldiers are threatened and mistreated for their past activities they did at the time of war to the villagers. So, she does not want to tell all the stories she knows about the wartime to her offsprings. Roka says, "I don't tell and they don't ask much as well" (personal communication, May 20, 2018).

Some victims of the war who responded to this research also considered hiding some stories of the wartime because the stories are too sensitive. Gita Thapa said that her siblings knew the stories as they encountered the war. But her children are very young. Thapa said, "my eldest daughter who is 13 years old discusses about Maoist with friends. But we cannot 
share all our stories with children" (personal communication, May 21, 2018). Likewise, Meena Nepali does not tell her children much about the war because they do not ask. She has a son and a daughter. The son, elder child, studies in Kathmandu and the daughter stays with her grandparents. Nepali thinks that her children do not understand much about what had happened to their father and how she has been living since then:

My son does not understand much. He stayed away from a very young age so he does not feel my love much. I am not sure if my son has read the letter written by his father a day before he was killed (personal communication, May 21, 2018).

Any stories of the war that do not travel to the second person or any of the upcoming generations die as forgotten trauma. The new generations in this study know only few stories about the war because they are either not much interested into it or they are not told. While the news during the war might exist in the form of media archives, the possibility of them being read is too little unless they are interested. So, the tendency of forgetting the traumas experienced by their parent generation increases. Salina Gharti says that the story told by her mother is not adequate enough to understand what exactly had happened to their family during the war. She shares:

I don't have much interest in such things as how war used to take place. My mother also doesn't tell me much about father and how he was involved in the war and all. If I have to write any essays on the conflicts 
that happened, I don't think I can write much (personal communication, May 21, 2018).

While the undocumented stories need storytellers to travel through generations, the newer generations do not seem to comprehend the descriptions and details of what had happened. Sangita Budha knows only little about what had happened to her father though she has been studying free of cost in a school for being from a martyr's family:

I don't know anything about what happened then. My dad became a martyr. The government opened a school for the children of war victims. I was lucky enough to get to study there. So, I feel good. My mother sometimes talks about what she had been through during the war. But I remember nothing much. Our teachers never spoke anything of these things (personal communication, May 21, 2018).

In case the traumatic events are given emphasis by the first generation, they travel as war stories through different types of storytellers which is collectively called carrier group. There can be different types of carrier groups; victims or victors, witness and media. Victims are those who experience the events as directly involved people in the war. Sometimes, the storyteller may become the victor instead. Another carrier group termed as witness may include anyone who were not directly involved or affected but saw the traumatic events. Media can also be the storyteller of the wartime. They bring 
stories in the reported form which may remain as documented or undocumented stories depending on the nature of media and their archival features. All of these carrier groups may use their own filters, biases, and gatekeeping, which ultimate become the part of emphasis or distortion in transferring the stories from one generation to the other.

Emotional experiences are the real-time experiences filled with feelings and emotions during traumatic events, which form the context for war stories. These experiences come from the first generations because they are felt as events happen.

Second generation includes people who were born during the war but were too young to comprehend the events by themselves and thus needed interpretation from the earlier generation or those born in the post-conflict period. In other words, these people are those who hear the stories from a second source and are not the ones having first-hand experiences of the traumatic events or occurrences.

The traumatic interpretations contained in the stories that have been transferred from previous generation are termed as chosen trauma. In the study, most of the children from the newer generation, who did not encounter the war incidents were not grown up enough to comprehend the traumatic occurrences, describe the graphic schemas that are built in their mind through the stories they have heard from other sources. Their impressions about war are related to 'who did what to whom' where at least one from either Maoist or the state party become perpetrator while the other side become the victim. Sometimes, the stories are also based on how one 
side did harm to the people. Many stories the new generation know are based on their family's sufferings during the war:

My father was into Maoist. So, police used to chase him. Many people died. My father and his friends used to hide inside the dens. While coming home police would attempt to kill him. Grandparents were at home in Liwang. They broke my grandfather's hand. They also thrashed my grandmother. My father used to visit us at night and returned before the dawn (Sangita Budha, personal communication, May 20, 2018).

But some respondents were also aware about the consequences to the wider society. The younger generations have heard many stories. Based on those, they have made impressions about how the whole society suffered due to war.

I have heard that the poor had to suffer the most. Many poor people had to die and the state also did not give much attention to their sufferings. Others died too. Mom's friends also died. But, those who were directly involved in the war were the most vulnerable ones I think (Roshan Budha, personal communication, May 18, 2018).

Some children also explained that Maoist combatants forced people to tolerate them by entering into the houses and consuming all the food available in their grocery and the farm. Roshan Budha shares the story he knows about the insurgency: "Maoists used to enter the houses and finish all 
the grocery. If someone raised a voice, they were beaten up" (ibid).

Storyteller is anyone who learnt about or heard the stories of war or traumatic events of the past generations. They are not the actual victims or victors of the war or conflicts. Thus, communicators of the learnt stories are called storytellers. Sometimes the communities; schools or some collective groups become the storytellers which may also try to create discourse as preferred by them. Likewise, media in the second generation either tell the stories of the history or provide the evidences of previously told stories in the form of archives. Such media can be any channel of communication; from a personal letter to media of mass communication. In the third step of the narrative phenomenon, every element is common to that of the second generation including the interpretative reaction. However, every next generation is termed as the newer generation in the narrative phenomenon. Different generations may create different levels of emphasis or distortion depending on the context; meaning that some war stories are told better hundreds of years later while some other may die untold.

The chosen trauma are not the experiences of the communicators or storytellers but they come as interpretative reaction to what they have heard about the past. These chosen traumas have the tendency of being interpreted. Thus, this second step of the narrative phenomenon have many things in similar to that of first generation; emphasis, distortion, forgotten trauma, documented or undocumented stories. However, chosen trauma replaces traumatic events and 
storyteller replaces victims/victors, witness is replaced by communities, and archives added in place of media.

\section{Conclusion}

Stories of war travel from one generation to another when the people who experienced the traumatic events want to share their stories to the newer generations. Most often, particularly due to new and emerging media environment, the stories are told in the reported form by contemporary media. However, some stories die as they remain untold - which do not travel to the upcoming generations.

In the process of storytelling, storytellers; victims, victors, witness, media, community - all the carrier groups, as described in this model, use certain kinds of gatekeeping, biases and manipulative frames while they share their stories with different levels of emphasis. However, the filters or manipulative frames may also be understood as the distortion for the stories that do not pass onto the next generation.

Thus, evaluating the Narrative Phenomenon Model helps to understand that stories of conflict or war get created, modified or transformed. Stories get created with the occurrence of any violent events, if they are told. However, for any reasons; either due to distortion, emphasis or any kind of biases of the carrier groups or due to technological factors, if the facts get twisted or any untold facts get emerged, the stories get modified introducing newer or multiple truths. This is also possible due to the newer perspectives the storyteller may take 
into account while interpreting the facts. But, if the stories negate the existing facts or truths, they get transformed.

\section{References}

Alexander, J. C. (2012). Trauma: A social theory. Cambridge: Polity.

Alwin, D. F., \& McCammon, R. J. (2003). Generations, cohorts, and social change. In M. T. Jeylan, \& Shanahan, M.J. (Eds.), Handbook of the Life Course (pp.23-4. New York: Kluwer Academic/Plenum Publishers.

Eyerman, R. (2011). Political Assassination. The Cultural Sociology of Political Assassination. New York: Palgrave Macmillan.

Eyerman, R. (2012). Cultural trauma: Emotion and narration. Oxford: Oxford University Press.

Manchanda, R. (2004). Maoist Insergency in Nepal. Cultural Dynamics, 16(2/3), 237-256.

Mannheim, K. (1952). The problem of generations. In P. Kecskemeti (Ed.), Karl Mannheim: Essays (pp. 276-322). Routledge.

Roberts, C. W., \& Lang, K. (2001). Generations and Ideological Change: Some Observations. Public Opinion Quarterly, 49 (460).

Unger, B. L. Zamboanga, \& Szapocznik, J.Eds.) The American Psychologist, 65 (4), 237-251.

The author is an Assistant Professor at the Department of Languages and Mass Communication, School of Arts, Kathmandu University. Email: chandiraj.dahal@ku.edu.np 